\title{
Fiscal Policy And Economic Growth: The Effect of Fiscal Volatility
}

Abdiweli M. Ali, (Email: amali@niagara.edu), Niagara University

\begin{abstract}
This paper investigates the effect of fiscal policy on economic growth. Unlike the literature on growth that emphasizes the level and the nature of fiscal parameters, this paper focuses on the effect of fiscal volatility on economic growth. The literature on growth ignores the microeconomic instability associated with frequent changes of fiscal policy. The empirical results of this paper indicate that the effect of fiscal policy on economic growth is inconclusive. Most of the fiscal policy parameters commonly used in the growth literature had failed to explain growth differences across countries. However, when fiscal policy instability variables are used in the growth equation, almost all of the variables are significantly and negatively correlated with economic growth.
\end{abstract}

\section{INTRODUCTION}

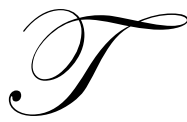

he empirical studies of fiscal policy and economic growth have concentrated predominantly on the effect of the level of fiscal parameters on economic growth and largely ignored the volatility of fiscal policy. The volatility of fiscal policy adversely affects the decisions of entrepreneurs and economic agents. From this point of view, the stability and predictability of the fiscal parameters are more important than the nature of the fiscal policy regime.

This paper investigates the relationship among fiscal parameters, the volatility of fiscal policy, and their effect on economic growth. The remainder of the paper is organized as follows. Section two is a review of prior empirical studies. Section three reexamines the empirical results of the effect of fiscal policy on economic growth. Section four assesses the relationship between fiscal volatility and economic growth, while section five concludes and makes suggestions for further research.

\section{FISCAL POLICY AND ECONOMIC GROWTH: AN OVERVIEW OF PRIOR EMPIRICAL STUDIES}

The effect of fiscal policy on economic growth has been one of the most debated and controversial issues in economics. There is a voluminous empirical literature examining the relationship between fiscal policy and economic growth. Some of the latest contributions include Levine and Renelt (1992), Engen and Skinner (1992), Easterly and Rebelo (1993), Easterly and others (1993), Villanueva (1994), Lin (1994), Kormendi and Meguire (1985), Landau (1986), Skinner (1987), Ram (1986) and (1987), Grier and Tullock (1989), Koester and Kormendi (1989), and Barro (1989 and 1991).

One of the fiscal parameters that is considered to have a negative impact on economic growth is the size of government budget deficit. The standard explanation in the literature is that government deficit crowd-out private capital formation by increasing interest rate and reducing the amount of savings available for private investors. To the extent that deficits are used for investment purposes, the country's total capital formation might not necessarily decline. However, the relative productivity of public and private capital can affect the pace of economic growth and as long as the return to public capital is below that of private capital, deficits will negatively affect the GDP growth rate. 
Contrary to this view, the Ricardian equivalence proposition suggests that government deficit has no effect on economic growth. Because current government deficits must eventually be paid with higher taxes in the future, households will save more now to pay the higher taxes in the future. ${ }^{1}$

Another element of fiscal policy that influences the rate of economic growth is the level of government spending. Barro (1989 and 1991) finds that per capita GDP growth rate and investment-GDP ratio, are negatively correlated to government expenditure as a share of the GDP. Barro (1991) suggested that government consumption induces distortions in the economy and provides no offsetting stimulus to GDP and investment.

Kormendi and Meguire (1985) find no evidence that the growth in the ratio of government consumption to output has any adverse effect on economic growth. Following Kormendi and Meguire and using a larger sample of countries including both the OECD and developing countries, Grier and Tullock (1989) find a strong negative correlation between growth of government consumption as a fraction of GDP and real GDP growth rate. Similarly, Landau (1986) in a cross-section study of 96 countries finds that government consumption reduces growth in four sample periods (1961-70, 61-72, 61-74 and 61-76).

Easterly and others (1993) failed to find a significant correlation between growth and government consumption share of the GDP. In a more comprehensive summary of the association between measures of fiscal policy and the rate of growth, Easterly and Rebelo (1993) find that the effect of fiscal variables on economic growth are statistically fragile. The only fiscal variable in their study that is consistently correlated with the growth of GDP and private investment is the government budget surplus.

A more important dimension in the analysis of fiscal policy and economic growth is the extent to which fiscal spending is financed through distortionary taxation. Distortionary taxation lowers the incentive to save and invest, thereby lowering the rate of capital accumulation and economic growth. A number of cross-section studies have analyzed the relationship between taxation and growth differences across countries. A review of this literature is in Ireland (1994). The statistical results from these studies are inconclusive. While some studies find that taxes have effects on long-term growth rate, others find no significant effect. After controlling for the initial level of GDP and using different tax measures, Koester and Kormendi (1989) find that average and marginal tax rates are negatively correlated with growth. However, the coefficients of both the marginal and average tax rates are not statistically significant. Likewise, Easterly and Rebelo (1993) concluded the evidence that tax rates matter for growth is fragile. When they controlled for other correlates of growth, only the marginal income tax rate and the ratio of income taxes to personal income remained significant in their cross-country regressions.

Helms (1985) analyzed the growth effects of state and local taxes. He argues that higher taxes can stimulate economic growth if used to finance development expenditures. After controlling for all sources and uses of taxes in a pooled time-series-cross-section regressions in the period 1965-1975, Helms finds that taxes have a negative and significant effect on growth. The Helms regressions indicate that the coefficient of the tax rate can be positive if taxes finance productive expenditures, and can be negative if tax receipts are used to finance welfare transfers. Redistributive public transfers can adversely affect the pace of economic growth. Alesina and Rodrik (1994) and Lee (1992) find that for a given tax rate, an increase in public transfers reduces the rate of economic growth. In a crosssection empirical work, Barro (1989) and Barro and Sala-i-Martin (1992b) find that holding the size of government constant, public transfers are positively correlated to per capita income growth rate.

\section{FISCAL POLICY AND ECONOMIC GROWTH: RE-TESTING THE EMPIRICAL RELATIONSHIPS}

Using several fiscal policy parameters currently used in the growth literature, this section re-estimates the relationship between fiscal policy and economic growth. Most of the variables are from the World Development Indicators of the World Bank. The data is from 1975-1998 and covers over 90 countries. A description of the variables is in Appendix A.

\footnotetext{
${ }^{1}$ For further analysis of this theory, see Barro (1974).
} 
Table 1 reports the empirical results of the relationship between fiscal policy and economic growth when 9 fiscal policy parameters are entered into the growth equation. The dependent variable in Table 1 is the average growth rate of GDP per capita from 1975-1998. Because heteroskedasticity can be important across countries, the standard errors are based on White's (1980) Heteroskedasticity-Consistent Covariance Matrix. The specification of the growth equation is similar to that adopted in Barro (1996) and Levine and Renelt (1992).

Table 1: The Effect of Fiscal Policy on Economic Growth

Dependent Variable: Real GDP Growth Rate (1975-1998)

\begin{tabular}{|c|c|c|c|c|c|c|c|c|c|c|}
\hline $\begin{array}{l}\text { Independent } \\
\text { Variables }\end{array}$ & 1 & 2 & 3 & 4 & 5 & 6 & 7 & 8 & 9 & 10 \\
\hline SECE & $\begin{array}{l}-0.005 \\
(-0.49)\end{array}$ & $\begin{array}{l}-0.010 \\
(-0.85)\end{array}$ & $\begin{array}{l}0.016 \\
(1.35)\end{array}$ & $\begin{array}{l}-0.006 \\
(-.559)\end{array}$ & $\begin{array}{l}0.025 \\
(1.204)\end{array}$ & $\begin{array}{l}0.0041 \\
(1.089)\end{array}$ & $\begin{array}{l}0.018 \\
(1.34)\end{array}$ & $\begin{array}{l}0.026 \\
(1.45)\end{array}$ & $\begin{array}{l}-0.113 \\
(-0.95)\end{array}$ & $\begin{array}{l}-0.023 \\
(-0.59)\end{array}$ \\
\hline GDP75 & $\begin{array}{l}0.011 \\
(0.81)\end{array}$ & $\begin{array}{l}0.021 \\
(1.092)\end{array}$ & $\begin{array}{l}-0.003 \\
(-0.24)\end{array}$ & $\begin{array}{l}0.009 \\
(0.639)\end{array}$ & $\begin{array}{l}-0.001 \\
(-0.04)\end{array}$ & $\begin{array}{l}-0.0071 \\
(-0.38)\end{array}$ & $\begin{array}{l}-0.033 \\
(-0.76)\end{array}$ & $\begin{array}{l}-0.052 \\
(-0.29)\end{array}$ & $\begin{array}{l}0.0311 \\
(1.365)\end{array}$ & $\begin{array}{l}0.019 \\
(0.622)\end{array}$ \\
\hline GPOP & $\begin{array}{l}0.002 \\
(0.27)\end{array}$ & $\begin{array}{l}0.004 \\
(0.42)\end{array}$ & $\begin{array}{l}-0.004 \\
(-0.05) \\
\end{array}$ & $\begin{array}{l}0.003 \\
(0.377)\end{array}$ & $\begin{array}{l}0.003 \\
(0.316) \\
\end{array}$ & $\begin{array}{l}0.0193 \\
(0.251) \\
\end{array}$ & $\begin{array}{l}-0.0051 \\
(-0.09) \\
\end{array}$ & $\begin{array}{l}-0.040 \\
(-0.57) \\
\end{array}$ & $\begin{array}{l}0.0187 \\
(0.92) \\
\end{array}$ & $\begin{array}{l}0.0198 \\
(0.383) \\
\end{array}$ \\
\hline DEBT & & $\begin{array}{l}-1.87 \\
(-0.35)\end{array}$ & & & & & & & & \\
\hline $\begin{array}{l}\text { General } \\
\text { Government } \\
\text { Consumption }\end{array}$ & & & $\begin{array}{l}0.010 \\
(1.51)\end{array}$ & & & & & & & \\
\hline DEFICIT & & & & $\begin{array}{l}-0.008 \\
(-1.18) \\
\end{array}$ & & & & & & \\
\hline TAXES & & & & & $\begin{array}{l}-0.009 \\
(-1.23) \\
\end{array}$ & & & & & \\
\hline $\begin{array}{l}\text { Current } \\
\text { Revenue }\end{array}$ & & & & & & $\begin{array}{l}-0.023 \\
(1.016)\end{array}$ & & & & \\
\hline $\begin{array}{l}\text { Net Indirect } \\
\text { Taxes }\end{array}$ & & & & & & & $\begin{array}{l}-0.145 \\
(-0.94)\end{array}$ & & & \\
\hline Direct Taxes & & & & & & & & $\begin{array}{l}-0.237 \\
(-1.42) \\
\end{array}$ & & \\
\hline Trade Taxes & & & & & & & & & $\begin{array}{l}-0.985 \\
(-1.53)\end{array}$ & \\
\hline $\begin{array}{l}\text { Current } \\
\text { Transfers }\end{array}$ & & & & & & & & & & $\begin{array}{l}0.0224 \\
(0.837) \\
\end{array}$ \\
\hline $\mathbf{C}$ & $\begin{array}{l}0.152 \\
(1.38)\end{array}$ & $\begin{array}{l}0.059 \\
(0.41)\end{array}$ & $\begin{array}{l}0.175 \\
(1.73)\end{array}$ & $\begin{array}{l}0.164 \\
(1.39)\end{array}$ & $\begin{array}{l}0.159 \\
(153)\end{array}$ & $\begin{array}{l}0.322 \\
(1.14)\end{array}$ & $\begin{array}{l}0.179 \\
(1.45)\end{array}$ & $\begin{array}{l}0.098 \\
(1.33)\end{array}$ & $\begin{array}{l}0.177 \\
(1.55)\end{array}$ & $\begin{array}{l}0.162 \\
(1.37)\end{array}$ \\
\hline Observations & 90 & 63 & 85 & 87 & 85 & 85 & 87 & 85 & 85 & 87 \\
\hline $\begin{array}{l}\text { Method of } \\
\text { Estimation }\end{array}$ & OLS & OLS & OLS & OLS & OLS & OLS & OLS & OLS & OLS & OLS \\
\hline $\mathbf{R}^{2}$ & 0.035 & 0.026 & 0.106 & 0.023 & 0.053 & 0.045 & 0.067 & 0.023 & 0.111 & 0.068 \\
\hline
\end{tabular}

T-statistics are in parentheses.

The basic regression results are in Model 1 of Table 1 . The explanatory variables are standard in the literature including a proxy for the initial level of income and the level of human capital as well as the population growth rate. Most of the empirical literature on growth includes one or more of these conditioning variables. The initial GDP level is negatively and significantly correlated with the GDP growth rate when controlled for other correlates of economic growth confirming the conditional convergence hypothesis of Barro (1991), Barro and Sala-iMartin (1992), Levine and Renelt (1992), and Barro (1996). All of the other control variables are significant as suggested by the current literature on growth.

Column 2 adds the level of public debt into the basic regression equation. The coefficient of public debt is insignificant. Column 3 includes general government consumption as an additional explanatory variable. Again, the result indicates that the level of government expenditure has no explanatory power on growth. Its coefficient is 
insignificant with the unexpected positive sign. Columns 4 and 5 report the regression results for total taxes and total budget deficit. Both variables have no significant impact on growth. The coefficients of both variables are negative and insignificant. Columns 6 and 7 add current revenue and net indirect taxes into the core regression equation. Again, the coefficients of both variables are negative and statistically insignificant. Columns 8 and 9 report the results when direct taxes and trade taxes are the additional explanatory variables. Both coefficients are insignificant at the conventional level. Finally, column 10 reports the regression results when current transfer is included in the regression equation. Its coefficient is positive and insignificant.

It is plausible that the relationship between fiscal policy and economic growth is indirect through the investment channel. Table 2 reports the results when the investment share of the GDP is used as the dependent variable. Columns 1-9 add fiscal policy variables in the core investment equation. In each model, one of the fiscal parameters is added as an additional variable of interest. None of these variables have any explanatory power in explaining cross-country differences of the level of investment except for budget deficit and trade taxes.

Table 2: The Effect of Fiscal Policy on Economic Growth

Dependent Variable: Investment/GDP (1975-1998)

\begin{tabular}{|c|c|c|c|c|c|c|c|c|c|c|}
\hline $\begin{array}{l}\text { Independent } \\
\text { Variables }\end{array}$ & 1 & 2 & 3 & 4 & 5 & 6 & 7 & 8 & 9 & 10 \\
\hline SECE & $\begin{array}{l}-0.004 \\
(-0.38) \\
\end{array}$ & $\begin{array}{l}-0.021 \\
(-0.96) \\
\end{array}$ & $\begin{array}{l}0.027 \\
(1.46) \\
\end{array}$ & $\begin{array}{l}-0.017 \\
(-0.44) \\
\end{array}$ & $\begin{array}{r}-0.004 \\
(-1.31) \\
\end{array}$ & $\begin{array}{l}-0.005 \\
(-0.37) \\
\end{array}$ & $\begin{array}{l}0.0066 \\
(1.48)\end{array}$ & $\begin{array}{l}-0.060 \\
(-0.78)\end{array}$ & $\begin{array}{l}0.024 \\
(1.366) \\
\end{array}$ & $\begin{array}{l}-0.022 \\
(-0.55) \\
\end{array}$ \\
\hline GDP75 & $\begin{array}{l}0.022 \\
(0.92)\end{array}$ & $\begin{array}{l}0.010 \\
(1.103)\end{array}$ & $\begin{array}{l}-0.014 \\
(-0.35)\end{array}$ & $\begin{array}{l}0.010 \\
(0.740)\end{array}$ & $\begin{array}{l}-0.112 \\
(-0.15)\end{array}$ & $\begin{array}{l}0.123 \\
(0.99)\end{array}$ & $\begin{array}{l}-0.115 \\
(-0.39)\end{array}$ & $\begin{array}{l}0.120 \\
(0.768)\end{array}$ & $\begin{array}{l}-0.114 \\
(-0.10)\end{array}$ & $\begin{array}{l}0.0345 \\
(0.811)\end{array}$ \\
\hline GPOP & $\begin{array}{l}0.113 \\
(0.38)\end{array}$ & $\begin{array}{l}0.115 \\
(0.591)\end{array}$ & $\begin{array}{l}-0.116 \\
(-0.16)\end{array}$ & $\begin{array}{l}0.104 \\
(0.388)\end{array}$ & $\begin{array}{l}0.114 \\
(0.427)\end{array}$ & $\begin{array}{l}0.113 \\
(0.39)\end{array}$ & $\begin{array}{l}-0.118 \\
(-0.19)\end{array}$ & $\begin{array}{l}0.1069 \\
(0.580)\end{array}$ & $\begin{array}{l}0.123 \\
(0.472)\end{array}$ & $\begin{array}{l}0.1145 \\
(0.724)\end{array}$ \\
\hline DEBT & & $\begin{array}{l}-1.76 \\
(-0.35) \\
\end{array}$ & & & & & & & & \\
\hline DEFICIT & & & $\begin{array}{l}-0.021 \\
(-2.62)\end{array}$ & & & & & & & \\
\hline $\begin{array}{l}\text { General } \\
\text { Government } \\
\text { Consumption }\end{array}$ & & & & $\begin{array}{l}-0.119 \\
(-1.29)\end{array}$ & & & & & & \\
\hline TAXES & & & & & $\begin{array}{l}0.108 \\
(1.34)\end{array}$ & & & & & \\
\hline $\begin{array}{l}\text { Current } \\
\text { Revenue }\end{array}$ & & & & & & $\begin{array}{l}-0.202 \\
(-1.35) \\
\end{array}$ & & & & \\
\hline $\begin{array}{l}\text { Net Indirect } \\
\text { Taxes } \\
\end{array}$ & & & & & & & $\begin{array}{l}-0.432 \\
(-1.42) \\
\end{array}$ & & & \\
\hline Direct Taxes & & & & & & & & $\begin{array}{l}-0.102 \\
(-0.99)\end{array}$ & & \\
\hline Trade Taxes & & & & & & & & & $\begin{array}{l}-0.330 \\
(1.292)\end{array}$ & \\
\hline $\begin{array}{l}\text { Current } \\
\text { Transfers } \\
\end{array}$ & & & & & & & & & & $\begin{array}{l}-0.193 \\
(-0.49) \\
\end{array}$ \\
\hline $\mathrm{C}$ & $\begin{array}{l}0.263 \\
(1.49) \\
\end{array}$ & $\begin{array}{l}0.160 \\
(0.52) \\
\end{array}$ & $\begin{array}{l}0.186 \\
(1.84) \\
\end{array}$ & $\begin{array}{l}0.175 \\
(1.40) \\
\end{array}$ & $\begin{array}{l}0.161 \\
(1.141)\end{array}$ & $\begin{array}{l}0.184 \\
(1.79)\end{array}$ & $\begin{array}{l}0.288 \\
(2.45) \\
\end{array}$ & $\begin{array}{l}0.620 \\
(1.18)^{\circ}\end{array}$ & $\begin{array}{l}0.154 \\
(1.02) \\
\end{array}$ & $\begin{array}{l}0.988 \\
(4.10)\end{array}$ \\
\hline Observations & 90 & 63 & 85 & 87 & 85 & 87 & 87 & 85 & 87 & 87 \\
\hline $\begin{array}{l}\text { Method of } \\
\text { Estimation }\end{array}$ & OLS & OLS & OLS & OLS & OLS & OLS & OLS & OLS & OLS & OLS \\
\hline $\mathbf{R}^{2}$ & 0.115 & 0.136 & 0.117 & 0.134 & 0.064 & 0.174 & 0.188 & 0.147 & 0.134 & 0.172 \\
\hline
\end{tabular}

In summary, the effect of the level of fiscal policy parameters on growth is not clearly conclusive. The majority of the fiscal policy variables have no significant effect on the growth of GDP when other correlates of growth are included in the model. Furthermore, the empirical results also indicate that the level of fiscal policy parameters used in the growth literature is not able to explain cross-country differences in the level of investment. Nevertheless, 
fiscal policy may have a significant effect on economic growth operating indirectly through its effect on the stability of fiscal policy parameters, an issue that will be explored in the next section.

\section{FISCAL VOLATILITY AND ECONOMIC GROWTH}

The empirical studies of fiscal policy and economic growth have concentrated predominantly on the effect of the level of fiscal parameters on economic growth and largely ignored the volatility of these fiscal parameters. It is important to understand that the decisions of private investors depend on factors that are partly under the control of the government. Economic agents react negatively on the uncertainties about future taxes and the future behavior of fiscal parameters. For these entrepreneurs the stability and the predictability of fiscal instruments weigh heavily on their decision of whether to behave on way or another. As Pindyck (1988) suggested predictable policies and clear rules of the game are important for private investors. The irreversible nature of most investments, he argued, makes investors extremely sensitive to changes of policies and the risks associated with it. Knowing that they cannot disinvest when fiscal policy changes, firms will delay investment and wait for new information before committing their resources. In an environment of constant shift of policies, it takes a long time before investors are convinced that changes of fiscal policies are permanent. They cannot undo decisions about fixed capital every time the government reverses its fiscal policy regime.

Following Aizenman and Marion (1991), the unexpected effect of fiscal policy can be calculated by fitting a first-order autoregressive process of the form:

$(\text { Fiscal Policy })_{\mathrm{t}}=\mathrm{B}_{0}+\mathrm{B}_{1}(\text { Fiscal Policy })_{\mathrm{t}-1}+\varepsilon$

where $\mathrm{B}_{1}$ is the autoregressive parameter.

The standard deviation of the residual (ع) measures the variability or the uncertainty associated with changes in fiscal policy. The fiscal policy instability variables are then included in the growth equation in the form:

GDP7598 $=\left(\beta_{0}\right)+\left(\beta_{1}\right)$ GDP75 $+\left(\beta_{2}\right)$ Population7598 $+\left(\beta_{3}\right)$ Schooling75 $+\left(\beta_{4}\right)$ Fiscal Policy Uncertainty $+\varepsilon$

Table 3 reports the regression results. Almost all of the fiscal policy uncertainty variables are significantly and negatively correlated with economic growth when controlled for other relevant exogenous variables. Column 1 contains the benchmark regression equation. Column 2 contains the core variables and the standard deviation of the residual (here on as SDR) of government debt as a measure of fiscal policy uncertainty. The SDR captures the unexpected component of the fiscal policy. The coefficient of public debt is negative and significant at the onepercent level.

Column 3 shows the correlation between the SDR of government's consumption share of the GDP and economic growth. Its coefficient is significant and of the expected sign. Evaluating the effect at the sample mean, the estimated coefficient indicates that a one-standard deviation increase in the SDR of public debt reduces the growth rate by 1.03 - percent change.

Columns 4 and 5 add the SDR of tax revenue as a percent of the GDP and the overall budget deficit into the growth equation. Both coefficients are negative and highly significant. However, the correlation between the SDR of current revenue in column 6 is rather weak. The coefficient of current revenue is not significant at the conventional level. Column 7 adds the SDR of indirect taxes into the benchmark equation. The volatility of tax revenue has no noticeable impact on economic growth. Columns 8 and 9 contain the basic regression equation and the SDR of direct taxes and trade taxes. Both coefficients are negative and highly significant. Finally, column 10 augments the benchmark equation with the SDR of current transfers as an additional variable of interest. The coefficient of the current transfer is negative but not significant at the 5 percent level. 
Table 3: The Effect of Fiscal Volatility on Economic Growth

Dependent Variable: Real GDP Growth Rate (1975-1998)

\begin{tabular}{|c|c|c|c|c|c|c|c|c|c|c|}
\hline $\begin{array}{l}\text { Independent } \\
\text { Variables }\end{array}$ & 1 & 2 & 3 & 4 & 5 & 6 & 7 & 8 & 9 & 10 \\
\hline SECE & $\begin{array}{l}0.0067 \\
(2.47)\end{array}$ & $\begin{array}{l}0.00385 \\
(1.0911)\end{array}$ & $\begin{array}{l}0.00569 \\
(2.0717)\end{array}$ & $\begin{array}{l}0.00488 \\
(1.7477)\end{array}$ & $\begin{array}{l}0.00533 \\
(1.1891)\end{array}$ & $\begin{array}{l}0.00559 \\
(1.982)\end{array}$ & $\begin{array}{l}0.00761 \\
(1.677)\end{array}$ & $\begin{array}{l}0.00566 \\
(2.0081)\end{array}$ & $\begin{array}{l}0.00843 \\
(1.771)\end{array}$ & $\begin{array}{l}0.00348 \\
(2.115)\end{array}$ \\
\hline GDP75 & $\begin{array}{l}-0.0078 \\
(-2.524)\end{array}$ & $\begin{array}{l}-0.0066 \\
(-1.527)\end{array}$ & $\begin{array}{l}.00775 \\
(-2.386)\end{array}$ & $\begin{array}{l}-0.0079 \\
(-2.348)\end{array}$ & $\begin{array}{l}-0.0033 \\
(-2.035)\end{array}$ & $\begin{array}{l}-.00927 \\
(-2.384)\end{array}$ & $\begin{array}{l}-.00587 \\
(-2.483)\end{array}$ & $\begin{array}{l}.00555 \\
(-1.901)\end{array}$ & $\begin{array}{l}-.00451 \\
(2.110)\end{array}$ & $\begin{array}{l}-00853 \\
(-.297)\end{array}$ \\
\hline GPOP & $\begin{array}{l}-0.0080 \\
(-3.435)\end{array}$ & $\begin{array}{l}-.00778 \\
(-2.245)\end{array}$ & $\begin{array}{l}-.00683 \\
(-2.894)\end{array}$ & $\begin{array}{l}-0.0081 \\
(-3.496)\end{array}$ & $\begin{array}{l}-.00721 \\
(-2.118)\end{array}$ & $\begin{array}{l}-.00836 \\
(-2.425)\end{array}$ & $\begin{array}{l}-.00182 \\
(-3.452)\end{array}$ & $\begin{array}{l}-0.0091 \\
(-3.263)\end{array}$ & $\begin{array}{l}-0.0029 \\
(-3.254)\end{array}$ & $\begin{array}{l}-.0022 \\
(-.991)\end{array}$ \\
\hline SDR DEBT & & $\begin{array}{l}1.6712 \\
(-2.474)\end{array}$ & & & & & & & & \\
\hline $\begin{array}{l}\text { SDR General } \\
\text { Government } \\
\text { Consumption }\end{array}$ & & & $\begin{array}{l}-.00489 \\
(-3.120)\end{array}$ & & & & & & & \\
\hline $\begin{array}{l}\text { SDR Total } \\
\text { Government } \\
\text { Expenditure }\end{array}$ & & & & $\begin{array}{l}-.00325 \\
(-1.985)\end{array}$ & & & & & & \\
\hline SDR DEFICIT & & & & & $\begin{array}{l}.00124 \\
(-1.783)\end{array}$ & & & & & \\
\hline $\begin{array}{l}\text { SDR Current } \\
\text { Revenue }\end{array}$ & & & & & & $\begin{array}{l}-0.0432 \\
(1.4571)\end{array}$ & & & & \\
\hline $\begin{array}{l}\text { SDR Net } \\
\text { Indirect Taxes }\end{array}$ & & & & & & & $\begin{array}{l}-.00521 \\
(-1.191) \\
\end{array}$ & & & \\
\hline $\begin{array}{l}\text { SDR Direct } \\
\text { Taxes }\end{array}$ & & & & & & & & $\begin{array}{l}-0.2521 \\
(2.3241) \\
\end{array}$ & & \\
\hline $\begin{array}{l}\text { SDR Trade } \\
\text { Taxes }\end{array}$ & & & & & & & & & $\begin{array}{l}.01023 \\
(-3.125) \\
\end{array}$ & \\
\hline $\begin{array}{l}\text { SDR Current } \\
\text { Transfers }\end{array}$ & & & & & & & & & & $\begin{array}{l}0.5183 \\
(1.3141) \\
\end{array}$ \\
\hline C & $\begin{array}{l}0.05417 \\
(2.1854)\end{array}$ & $\begin{array}{l}0.04139 \\
(1.3043)\end{array}$ & $\begin{array}{l}0.05607 \\
(2.1768)\end{array}$ & $\begin{array}{l}0.04787 \\
(1.9059)\end{array}$ & $\begin{array}{l}0.0367 \\
(1.4132)\end{array}$ & $\begin{array}{l}0.0744 \\
(1.1382)\end{array}$ & $\begin{array}{l}0.1911 \\
(2.3901)\end{array}$ & $\begin{array}{l}0.0088 \\
(3.331)\end{array}$ & $\begin{array}{l}0.077 \\
(1.521)\end{array}$ & $\begin{array}{l}0.0515 \\
(2.221)\end{array}$ \\
\hline $\begin{array}{l}\text { Number of } \\
\text { Observations }\end{array}$ & 83 & 57 & 81 & 79 & 82 & 79 & 81 & 81 & 79 & 82 \\
\hline $\begin{array}{l}\text { Method of } \\
\text { Estimation }\end{array}$ & OLS & OLS & OLS & OLS & OLS & OLS & OLS & OLS & OLS & OLS \\
\hline $\mathbf{R}^{2}$ & 0.346 & 0.499 & 0.51 & 0.492 & 0.441 & 0.531 & 0.379 & 0.452 & 0.522 & 0.478 \\
\hline
\end{tabular}

T-statistics are in parentheses.

Again, it is possible that the relationship fiscal volatility might not only affect the growth of GDP but might also affect economic growth through the investment channel. Table 4 reports the statistical results of the relationship between fiscal policy instability and investment share of the GDP. The findings in Table 4 suggest that fiscal volatility have no significant impact on the accumulation of physical capital.

\section{CONCLUDING REMARKS}

This paper tested the relationship among fiscal parameters, the volatility of fiscal policy parameters, and economic growth. The level and the nature of fiscal parameters failed to fully capture the uncertainties associated with constantly changing fiscal policies. The paper presents the empirical results of the relationship between economic growth and several fiscal parameters using appropriate econometric techniques. The empirical results indicate that fiscal volatility has a more dramatic and significant impact on growth than the type of fiscal policy regime.

The impact of fiscal policy on economic growth is not conclusive. Most of the fiscal parameters currently used in the literature have no significant impact on economic growth either directly or indirectly. The empirical 
results also indicate that fiscal volatility is strongly and negatively correlated with economic growth. The results in Table 3 suggest that a variety of fiscal policy uncertainty variables are closely and negatively associated with economic growth. Although economic growth is not significantly and negatively correlated with every fiscal policy uncertainty variable, the data indicates that after controlling for a set of economic variables, fiscal policy uncertainty variables account a significant portion of growth differences across countries.

Table 4: The Effect of Fiscal Volatility on Economic Growth

Dependent Variable: Investment/GDP (1975-1998)

\begin{tabular}{|c|c|c|c|c|c|c|c|c|c|c|}
\hline $\begin{array}{l}\text { Independent } \\
\text { Variables }\end{array}$ & 1 & 2 & 3 & 4 & 5 & 6 & 7 & 8 & 9 & 10 \\
\hline SECE & $\begin{array}{l}-.226 \\
(-.69) \\
\end{array}$ & $\begin{array}{l}-0.232 \\
(-1.07) \\
\end{array}$ & $\begin{array}{l}0.238 \\
(1.57)\end{array}$ & $\begin{array}{l}-0.227 \\
(-0.77) \\
\end{array}$ & $\begin{array}{l}0.237 \\
(1.426)\end{array}$ & $\begin{array}{l}0.294 \\
(1.57)\end{array}$ & $\begin{array}{l}-0.233 \\
(-0.75) \\
\end{array}$ & $\begin{array}{l}-0.232 \\
(-0.36) \\
\end{array}$ & $\begin{array}{l}-0.225 \\
(-0.87) \\
\end{array}$ & $\begin{array}{l}0.239 \\
(1.466)\end{array}$ \\
\hline GDP75 & $\begin{array}{l}0.233 \\
(0.63) \\
\end{array}$ & $\begin{array}{l}0.243 \\
(1.104)\end{array}$ & $\begin{array}{l}-.225 \\
(-.46) \\
\end{array}$ & $\begin{array}{l}0.221 \\
(0.859)\end{array}$ & $\begin{array}{l}-0.223 \\
(-0.26) \\
\end{array}$ & $\begin{array}{l}-0.235 \\
(-.46) \\
\end{array}$ & $\begin{array}{l}0.326 \\
(1.226)\end{array}$ & $\begin{array}{l}0.243 \\
(0.954)\end{array}$ & $\begin{array}{l}0.2213 \\
(0.66) \\
\end{array}$ & $\begin{array}{l}-0.122 \\
(-0.57)\end{array}$ \\
\hline GPOP & $\begin{array}{l}0.204 \\
(0.49) \\
\end{array}$ & $\begin{array}{l}0.106 \\
(0.64) \\
\end{array}$ & $\begin{array}{l}-.026 \\
(-.27) \\
\end{array}$ & $\begin{array}{l}0.225 \\
(0.599)\end{array}$ & $\begin{array}{l}0.1050 \\
(0.528) \\
\end{array}$ & $\begin{array}{l}-0.137 \\
(-.83) \\
\end{array}$ & $\begin{array}{l}0.1226 \\
(0.846) \\
\end{array}$ & $\begin{array}{l}0.244 \\
(0.591) \\
\end{array}$ & $\begin{array}{l}0.229 \\
(0.49) \\
\end{array}$ & $\begin{array}{l}0.2255 \\
(0.675) \\
\end{array}$ \\
\hline $\begin{array}{l}\text { SDR } \\
\text { DEBT }\end{array}$ & & $\begin{array}{l}1.097 \\
(0.560)\end{array}$ & & & & & & & & \\
\hline $\begin{array}{l}\text { SDR } \\
\text { DEFICIT }\end{array}$ & & & $\begin{array}{l}0.232 \\
(2.73) \\
\end{array}$ & & & & & & & \\
\hline $\begin{array}{l}\text { SDR General } \\
\text { Government } \\
\text { Consumption }\end{array}$ & & & & $\begin{array}{l}-0.220 \\
(-1.38)\end{array}$ & & & & & & \\
\hline $\begin{array}{l}\text { SDR } \\
\text { TAXES }\end{array}$ & & & & & $\begin{array}{l}0.221 \\
(1.45) \\
\end{array}$ & & & & & \\
\hline $\begin{array}{l}\text { SDR Current } \\
\text { Revenue }\end{array}$ & & & & & & $\begin{array}{l}-.223 \\
(-.35) \\
\end{array}$ & & & & \\
\hline $\begin{array}{l}\text { SDR Net } \\
\text { Indirect Taxes }\end{array}$ & & & & & & & $\begin{array}{l}-0.256 \\
(-0.93) \\
\end{array}$ & & & \\
\hline $\begin{array}{l}\text { SDR Direct } \\
\text { Taxes }\end{array}$ & & & & & & & & $\begin{array}{l}-0.261 \\
(-1.33) \\
\end{array}$ & & \\
\hline $\begin{array}{l}\text { SDR Trade } \\
\text { Taxes }\end{array}$ & & & & & & & & & $\begin{array}{l}-0.209 \\
(-2.36) \\
\end{array}$ & \\
\hline $\begin{array}{l}\text { SDR Current } \\
\text { Transfers }\end{array}$ & & & & & & & & & & $\begin{array}{l}-0.225 \\
(-0.25) \\
\end{array}$ \\
\hline $\mathbf{C}$ & $\begin{array}{l}0.374 \\
(1.50) \\
\end{array}$ & $\begin{array}{l}0.271 \\
(0.63) \\
\end{array}$ & $\begin{array}{l}0.397 \\
(1.95) \\
\end{array}$ & $\begin{array}{l}0.186 \\
(1.51) \\
\end{array}$ & $\begin{array}{l}0.171 \\
(1.59) \\
\end{array}$ & $\begin{array}{l}0.179 \\
(1.67) \\
\end{array}$ & $\begin{array}{l}0.169 \\
(1.88) \\
\end{array}$ & $\begin{array}{l}0.435 \\
(1.38) \\
\end{array}$ & $\begin{array}{l}0.203 \\
(1.66) \\
\end{array}$ & $\begin{array}{l}0.147 \\
(1.45) \\
\end{array}$ \\
\hline Observations & 90 & 63 & 85 & 87 & 85 & 87 & 85 & 85 & 87 & 87 \\
\hline $\begin{array}{l}\text { Method of } \\
\text { Estimation }\end{array}$ & OLS & OLS & OLS & OLS & OLS & OLS & OLS & OLS & OLS & OLS \\
\hline $\mathbf{R}^{2}$ & 0.057 & 0.048 & 0.228 & 0.045 & 0.075 & 0.054 & 0.077 & 0.090 & 0.337 & 0.056 \\
\hline
\end{tabular}

T-statistics are in parentheses.

Most of the coefficients of fiscal uncertainty are significant at the 5 percent level, and of the anticipated negative sign. The effect of fiscal volatility on economic growth is particularly strong for the case of government debt, direct taxes, trade taxes, budget deficit, as well as the government expenditure share of the GDP and the ratio of taxes to GDP. The effect of policy instability is less pronounced for the case of public transfers, and current revenue including grants.

Fiscal volatility does not appear to have much of an impact on capital accumulation. With the exception of government expenditure share of the GDP and trade taxes, all the other fiscal policy instability variables have no noticeable impact on economic growth. A further research is needed to seek a better understanding of how fiscal policy really affects economic growth. 


\section{REFERENCES}

1. Aizenman, Joshua; Marion, Nancy, 1991. "Policy Uncertainty, Persistence and Growth”, NBER Working Paper No. 3848.

2. Alesina, Alberto; Rodrik, Dani, 1994. "Distributive Politics and Economic Growth", Quarterly Journal of Economics, 109, 465-90.

3. Aschauer, David A., 1989. "Is Public Expenditure Productive?” Journal of Monetary Economics, 23, 177-200.

4. Barro, Robert J., Sala-I-Martin, Xavier, 1992b. "Public Finance in Models of Economic Growth", Review of Economic Studies, 59, 223-51.

5. 1991. "Convergence across States and Regions", Brooking Papers on Economic Activity, No. 1, 107-82.

6. 1991. "Economic Growth in A Cross Section of Countries", Quarterly Journal of Economics, $\overline{106,407-43 .}$

7. 1989. “A Cross-Country Study of Growth, Saving and Government”, NBER working paper No. 2855.

8. _ 1974. “Are Government Bonds Net Wealth?” Journal of Political Economy, November/ December, 1095-117.

9. Easterly, William, 1989. "Policy Distortions, Size of Government, and Growth", NBER Working Paper No. 3214.

10. 1990. "Endogenous Growth in Developing Countries With Government-Induced Distortions", A Discussion Paper, World Bank.

11. Rebelo, Sergio, 1993. "Fiscal Policy and Economic Growth", Journal of Monetary Economics, $32,417-58$.

12. _ _ Rebelo, Sergio; Kremer , Michael; Pritchett, Lant; Summers, Lawrence H. 1993. "Good Policy or Good Luck? Country Growth Performance and Temporary Shocks", Journal of Monetary Economics, 459-83.

13. Engen, Eric M.; Skinner, Jonathan, 1992. "Fiscal Policy and Economic Growth", NBER Working Paper, No. 4223.

14. Grier, Kevin; Tullock, Gordon, 1989. “An Empirical Analysis of Cross-National Economic Growth”, Journal of Monetary Economics, 24, 259-76.

15. Helms, L. Jay, 1985. "The Effect of State and Local Taxes on Economic Growth: A Time-Series CrossSection Approach", Review of Economics and Statistics, 67, 574-82.

16. Ireland, Peter N., 1994. "Two Perspectives on Growth and Taxes", Federal Reserve of Richmond Economic Quarterly, 80, 1-17.

17. Koester, Reinhard B., Kormendi, Roger C., 1989. "Taxation, Aggregate Activity, and Economic Growth: Cross-Country Evidence on Some Supply-Side Hypothesis”, Economic Inquiry, 27, 367-86.

18. Kormendi, R.C., Meguire, P.G., 1985. "Macroeconomic Determinants of Growth: Cross-Country Evidence", Journal of Monetary Economics, 16, 141-63.

19. Landau, Daniel, 1986. "Government and Economic Growth in the LDC's: An Empirical Study for 19601980", Economic Development and Cultural Change 35(1), 35-76.

20. Levine, Ross; Renelt, David, 1992. "A Sensitivity Analysis of Cross-Country Growth Regressions", American Economic Review, 82, 942-96.

21. Lin, Steven A. Y. "Government Spending and Economic Growth", Applied Economics, 26, 83-94.

22. _ Romer, David; Weil, David; 1992. "A Contribution to the Empirics of Economic Growth", Quarterly Journal of Economics, 107, 407-37.

23. Martin, Richard; Fardmanesh, Mohsen, 1990. "Fiscal Variables and Growth: A Cross-Sectional Analysis", Public Choice, 239-51.

24. Pindyck, Robert S., 1988. "Irreversible Investment, Capacity, Choice, and the Value of the Firm”, American Economic Review, 78 (5).

25. Ram, Rati, 1986. "Government Size and Economic Growth: A New Framework and Some Evidence From Cross-Section and Time Series Data", American Economic Review, 76, 191-203. 
26. Rama, Martin, 1995. "Empirical Investment Equations for Developing Countries", in Serven, L; Solimano, A. (eds), Striving for Growth after Adjustment: the Role of Capital Formation, The World Bank, Washington, D.C.

27. Rebelo, Sergio, 1991. "Long-Run Policy Analysis and Long-Run Growth”, Journal of Political Economy, 99, 500-21.

28. Skinner, Jonathan, 1987. "Taxation and Output Growth: Evidence from African Countries”, NBER Working Paper, No. 2335.

29. Stokey, Nancy L; Rebelo, Sergio, 1995. "Growth Effects of Flat Rate Taxes”, Journal of Political Economy, 103, 519-50.

30. Villanueva, Delano, 1994. "Openness, Human Development, and Fiscal Policies: Effects on Economic Growth and Speed of Adjustment", Staff Papers, IMF, 41, 1-29.

\section{APPENDIX A}

\section{Data Description (Fiscal Parameters)}

Public and publicly guaranteed debt (current US dollars)

The Overall Budget Deficit, Including Grants (\% of GDP)

Current Expenditure (Current Local Currency Unit (LCU)

Current Revenue, excluding grants (\% of GDP)

Current Revenue, excluding grants (Current LCU)

Current Transfers, receipts (BoP US\$)

External Debt, Total (Current US\$)

General Government Consumption (\% of GDP)

General Government Consumption (annual \% growth)

General Government Consumption (Constant 1987 US \$)

Net Indirect Taxes (Constant 1987 US \$)

Total government expenditure Including Transfers as a share of the GDP

Tax revenue (\% of GDP)

Taxes on Income, Profits and Capital Gains (\% of Total Taxes).

Taxes on International Trade (\% of Current Revenue). 
NOTES 